\title{
流域SS動態モデルとモニタリングデータに基づく 都市流域から手賀沼への放射性Cs供給量の評価 RADIOACTIVE CESIUM SUPPLY FROM WATERSHED TO LAKE TEGANUMA USING A SS MODEL IN WATERSHED AND MONITORING DATA
}

\author{
橋田創 $^{1} \cdot$ 二瓶泰雄 ${ }^{2} \cdot$ 上原浩 ${ }^{3} \cdot$ 湯浅岳史 $^{3} \cdot$ 佐藤祐一 $^{4}$ \\ Hajime HASHIDA, Yasuo NIHEI, Hiroshi UEHARA, Takashi YUASA \\ and Yuichi SATO

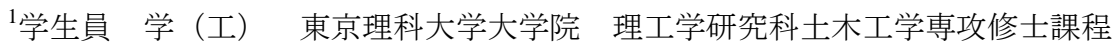 \\ （干278-8510 千葉県野田市山崎2641） \\ 2正会員 博 (工) 東京理科大学准教授 理工学部土木工学科（同上） \\ 3正会員 修 (工) パシフィックコンサルタンツ(株) \\ （†163-6018 東京都新宿区西新宿6-8-1） \\ 4正会員 博 (工) 滋賀県琵琶湖科学研究センター 主任研究員 綜合解析部門 \\ （テ520-0022＼cjkstart滋賀県大津市柳が崎5-34）
}

\begin{abstract}
Although watershed of Lake Teganuma have had a lot of radioactive hot spots since 2011, it is unclear when radioactive contamination in urban area, river and lake will be purified. This study attempts to evaluate radioactive cesium supply from the watershed to Lake Teganuma by using a distributed model for SS in watershed and monitoring data for radioactive cesium in watershed, river and lake. The present model is developed based on "SIPHER model" which is a distributed model for water and material cycles. The results indicate that 1) the present model can reproduce accurately temporal variations of river discharge and SS flux, and 2) the supply of radioactive cesium evaluated with the product of the simulated SS and measured cesium were good agreement with the observed data, showing the fundamental validity of the present approach.
\end{abstract}

Key Words: sediment transport, radioactive cesium, distributed model, Lake Teganuma

\section{1. 序論}

東京電力・福島第一原発から大量の放射性物質が放出 されて既に 3 年以上経過しているが (2014年 9月現在)， 原発周辺の地域では，未だに避難指示区域の設定が解除 されていない所も多い1)。また，原発から離れた地域の 放射能污染のホットスポットでも，市民生活への影響が 残り，放射能污染の問題は長期化している.この問題に 対処するには，放射能污染が，どの程度継続するかを適 切に評価・将来予測する必要があり，そのための継続的 なモニタリングやモデリング技術の開発が必要となる.

放射性物質の中で注目される放射性 Cs $\left({ }^{134} \mathrm{Cs}\right.$ と $\left.{ }^{137} \mathrm{Cs}\right)$ は 1 価の陽イオンを持つため, 化学的に土粒子と結合し やすく，一度結合すると分離しにくい ${ }^{2)}$ 。このため，陸 上に沈着した後の放射性セシウムの動態は, 流域におけ る土砂動態と類似すると考えられ，土粒子と結合した放 射性 Cs は降雨と共に流域〜河川～湖沼・海へと移動する 3）, 4) . 流域における放射性物質の動態に関する調査研究 は，森林域や農地を中心に行われてきた ${ }^{5)}$ ）．その一方 で，市民生活と直結する都市域における放射性物質動態
に関する研究事例は多くなく, 今後の課題とされており, 関連するシンポジウムも開催されている ${ }^{9)}$.

一方，著者らは，ホットスポットを抱える手賀沼流域 において，都市流域から河川，湖沼にわたる放射性 Cs の 動態や魚類への放射性 Cs 移行状況の現地調査を 2012 年 4 月から継続的に行っている (二瓶ら ${ }^{10)}$, 橋田ら ${ }^{11)}$, 以下, 前報と呼ぶ）。その結果, 都市流域では, 屋根面や路面, 側溝において高濃度の放射性 Cs 濃度を記録し, Cs 濃度の 時間的推移が屋根面と路面で異なることが示された。ま た，沼や河川（大堀川）下流域の底泥中の Cs 濃度は時間 的には明確に減少せず, 流域から高い Cs 濃度を持つ土粒 子が河川や湖沼に流入し続けていることが示された。底 泥污染と連動し魚類の放射能污染も継続している ${ }^{12)}$. こ のように放射性 Cs 動態のモニタリングはできているが, 動態の詳細や将来的な放射能污染状況の予測・評価には 至らず，流域の放射性物質動態モデルの開発が急務の課 題となっている.

著者らの一部は，様々な適用事例を有する流域水・物 質循環モデル (SIPHERモデル $\left.{ }^{13)}\right)$ をベースとして放射性 物質動態モデルやそれと関連するSS（Suspended Solids）動 


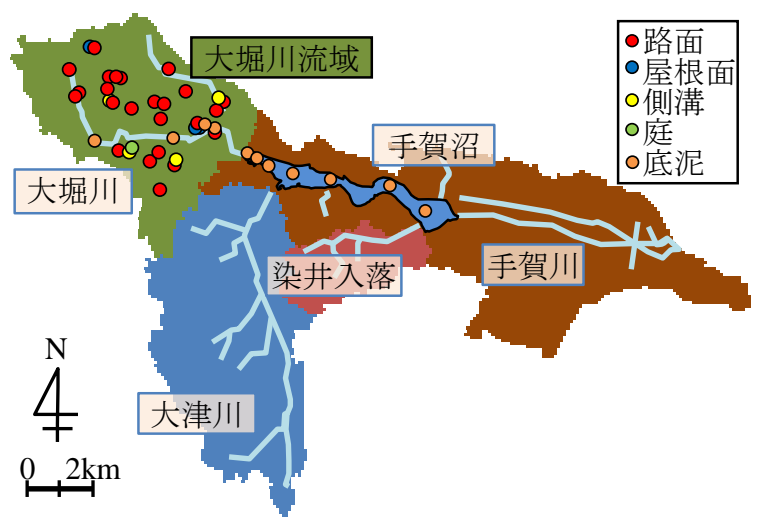

図-1 研究対象サイトと観測地点

表-1 手賀沼と流入河川の諸元

\begin{tabular}{|c|c|c|c|c|c|}
\hline & 手賀沼 & 大堀川 & 大津川 & 染井入落 \\
\hline \multicolumn{2}{|c|}{ 平均水深 $[\mathrm{m}]$} & 0.86 & & & \\
\hline \multicolumn{2}{|c|}{ 容積 $\left[\mathrm{m}^{3}\right]$} & 5600 & & & \\
\hline \multicolumn{2}{|c|}{ 全長 $[\mathrm{km}]$} & & 12.9 & 7.9 & 1.2 \\
\hline \multicolumn{2}{|c|}{ 流域面積 $\left[\mathrm{km}^{2}\right]$} & 144 & 31.0 & 35.9 & 8.90 \\
\hline \multirow{4}{*}{$\begin{array}{c}\text { 土地利用 } \\
{[\%]}\end{array}$} & 森林 & 11 & 13 & 14 & 28 \\
\hline & 水田 & 14 & 1 & 6 & 12 \\
\hline & 畑地 & 16 & 11 & 22 & 22 \\
\hline & 市街地 & 57 & 75 & 58 & 23 \\
\hline
\end{tabular}

態モデルを開発するとともに，琵琶湖流域への適用を行 っている．しかしながら，SSや放射性物質については実 測值との検証が十分行われておらず，モデルパラメータ のチューニングやモデル式の検討は今後の課題である. 本論文では，流域SS動態モデル及び放射性Csのモニタリ ングデータを用いて，流域から手賀沼への放射性Cs供給 量を推定する。ここでは，手賀沼流域を対象として，流 域SS動態モデルにより流域から河川，湖沼へのSSS輸送を 解析し, 観測值との比較から本モデルの妥当性を検証す る. また, 前報から継続して行われている放射性CS観測 を合わせて, 流域から河川を経由して湖沼に供給される 放射性Cs量を評価するとともに，手賀沼内でのCs蓄積量 と比較・検討を行う。

\section{2. 研究方法}

\section{(1) 研究対象サイト}

図-1 は，研究対象サイトである千葉県手賀沼とその流 入河川（大堀川，大津川，染井入落）及びそれらの流域 を示す．手賀沼や流入河川の諸元を表-1 亿示す．手賀沼 流域は都市化が進行し，市街地率は全体で $57 \%$ ，大堀川 流域では 75\%に達する. 手賀沼は 1974年〜2001 年まで水 質污濁度ワースト 1 を記録し，その要因の一つに流域か らの過剰な污濁負荷が挙げられる ${ }^{14)}$ 。このように，手賀 沼は, 流域環境変化の影響を受けや寸い立地条件である.

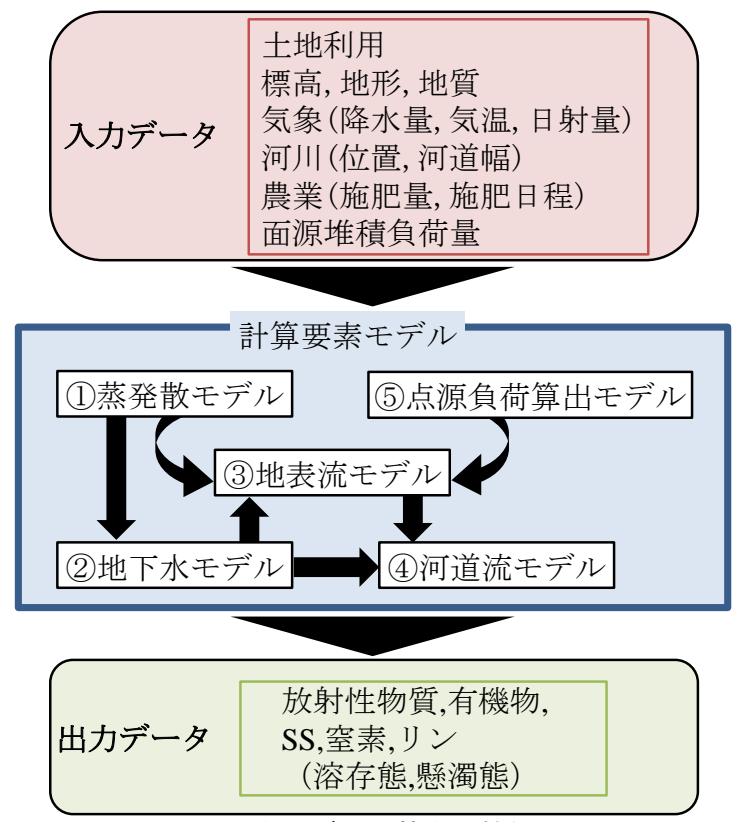

図-2 本モデルの基本的枠組み

放射能沈着マップを見ると ${ }^{15)}$ ，手賀沼流域は放射能污染 のホットスポットを含んでおり，特に北西部に位置する 大堀川流域ではその傾向が顕著である.

\section{(2) 現地観測の概要}

放射性 Cs 動態に関するモニタリング調查としては, 前 報から引き続き, 大堀川流域と手賀沼内を対象として, 都市流域の堆積土砂と河川・湖沼の底泥の放射性 Cs 計測 を行った．都市流域では，図-1 に示すように，路面と屋 根面, 側溝, 庭の 4 種類の被覆条件を対象として, 2012 年春から約 2 年間にわたり計 5 回の調査が行われた. 堆 積土砂をなるべく多く（体積で $1 \mathrm{~L}$ 以上）採取し，乾燥 炉にて $100^{\circ} \mathrm{C} て ゙ 24$ 時間乾燥させた後, $\mathrm{NaI}(\mathrm{TI})$ シンチレー ション搭載の高濃度用ベクレルモニター（AT1320A,

ATOMTEX社製）を用いて ${ }^{134} \mathrm{Cs}$ と ${ }^{137} \mathrm{Cs}$ を計測した。

河川・湖沼の底泥採取は，図-1 に示寸ように，大堀川 の上流〜下流の 4 地点, 湖沼全体にわたる 7 地点におい て行われた. 底泥に含まれる放射性 Cs の鉛直分布や総量 を把握するために，直径 $4 \mathrm{~cm}$ のアクリルパイプを用いて コアサンプルを採取した. パイプ長は河川: $30 \mathrm{~cm}$, 湖沼 : $1 \mathrm{~m}$ であり, 人力で突き刺さる深さまでのサンプルを取得 した．分析方法は前述と同様である．本調查は，2012年 6月から 2014年 7月に掛けて 6回行われたが,一回目にお ける河川の一部と湖沼では調查結果に不備が見られたの で解析対象外とした．なお，本調査の結果は前報に記載 されたものを含んでいる.

\section{（3）流域 SS 動態モデルの概要}

流域 SS 動態モデルとしては, 水・物質循環モデル （SIPHER モデル）をべースとした. 本モデルは, 図-2に 示すように, 蒸発散, 地下水, 地表流, 河道流, 点源負 荷を統合した分布型モデルであり，河川網や土地利用， 
標高，地質，気象等のデータをインプットデータとして 利用する．以下では，地表流モデルと河道流モデルにお いて組み込まれた SS 輸送方程式に関して記述する.

\section{1)地表流モデル}

一般に流域を格子分割する際には，各格子に一つの代 表的な土地利用データを与えるが, 格子サイズが $100 \mathrm{~m}$ オ 一ダー以上となるとそれでは土地利用状況を正確に反映 できない，そこで，本モデルでは，多様な土地利用デー タが失われないように，1格子内毎に土地利用割合を与 える. ここで対象とする地目としては, 水田, 山林, 畑, 宅地，道路，公園等，水面の 7 種類とする（後述の土地 利用番号 $j=1 \sim 7$ とする）。また，本モデルでは，SS 挙動 と窒素 $\mathrm{N}$ やリン $\mathrm{P}$ の懸濁態・溶存態成分とリンクしてモ デル化しているため, ここではSS 濃度を難分解性有機態 $\mathrm{SS}_{\mathrm{R}}$, 易分解性有機態 $\mathrm{SS}_{\mathrm{L}}$, 無機態 $\mathrm{SS}_{\mathrm{I}}$ の3 3 に分けて扱う.

地表流での SS 輸送を考慮するに当たり,地表流中の SS 濃度 $C^{l}$ と地表面上の単位面積当たりの堆積物量 $S^{l}$ の収 支を考える. まず $\mathrm{SS}$ の収支式は，混在する土地利用状況 を考慮し, 格子内の水量 $V$, 格子の平面面積 $A_{G}$ と寸るボ ックスを見立てて，次のように与えられる.

$$
\frac{\partial\left(C^{l} \cdot V\right)}{\partial t}=\left(L_{u}^{\prime}-L_{d}^{\prime}\right)+L_{p s}+A_{G}\left(\sum_{j=1}^{j \max } \lambda_{j} \cdot L_{n p s, j}\right)
$$

$-k_{S S} \cdot C^{l} \cdot V$

ここで, $L_{u}^{\prime}$ と $L_{d}^{\prime}$ は上・下流側の流入・流出 SS flux $(\mathrm{g} / \mathrm{hr})$, $L_{p s}$ はSS の点源負荷， $L_{n p s, j}$ は土地利用 $j$ における面源 負荷 $\left(\mathrm{g} /\left(\mathrm{m}^{2} \mathrm{hr}\right)\right) ， \lambda_{j}$ は土地利用 $j$ の面積率， $k_{S S}$ は SS の分解速度係数（易分解性有機態 $\mathrm{SS}_{\mathrm{L}}$ のみ考慮，1/hr） で ある. また，面源負荷 $L_{n p s, j}$ に関しては，水田とその他 （山林，畑，市街地（宅地，道路，公園等））で分けて 与える. 後者に関しては, 地表面の土壌流出として雨滴 衝撃 $G_{r f}$ と表面流出 $G_{r o}$ による発生を分けて取り扱う Hartley ${ }^{10}$ を参考にして, 土地利用毎の土畩流出量を面源負 荷 $L_{n p s, j}$ として算定している.

$$
\begin{aligned}
G_{r f, j} & =R\left(11.9+8.7 \log _{10} R\right)\left(1-\alpha_{1, j}\right) \cdot \alpha_{2, j} \cdot D_{m, j} \\
G_{r o, j} & =\rho_{w} g\left(\frac{60}{60+3140 \alpha_{1, j}{ }^{1.65}}\right) \frac{q_{L}}{2} i_{0} \cdot D_{m, j} \\
L_{n p s, j} & =\left(G_{r f, j}+G_{r o, j}\right) \cdot \frac{S^{l}{ }_{j}}{S^{l}{ }_{\text {max }, j}}
\end{aligned}
$$

ここで, $G_{r f, j}$ と $G_{r o, j}$ は雨滴衝撃と表面流出による土畩 流出量 $\left(\mathrm{g} /\left(\mathrm{m}^{2} \mathrm{hr}\right)\right), R$ : 時間降水量 $(\mathrm{mm} / \mathrm{hr}) ， \rho_{w}$ は水 の密度, $q_{L}$ : 単位幅流量 $\left(\mathrm{m}^{2} \mathrm{hr}\right), i_{0}$ : 傾斜, $\alpha_{1}, \alpha_{2}$ は 地表被覆パラメータ, $D_{m, j}$ は土壤侵食係数 $(\mathrm{g} / \mathrm{J}), S^{l}{ }_{j}$ と $S_{\text {max }, j}^{l}$ は地表面上の土砂堆積量とその最大值 $\left(\mathrm{kg} / \mathrm{m}^{2}\right)$

\begin{tabular}{|c|c|c|c|c|c|c|c|}
\hline \multicolumn{2}{|c|}{ (b) } & 水田 & 山林 & 畑 & 宅地 & 道路 & 公園等 \\
\hline \multicolumn{2}{|c|}{$\alpha_{1}$} & 0.200 & 0.800 & 0.700 & & 0.100 & \\
\hline \multicolumn{2}{|c|}{$\alpha_{2}$} & 0.400 & 0.300 & 0.400 & 0.900 & 1.000 & 0.900 \\
\hline \multirow{3}{*}{$\begin{array}{c}\text { 土壤浸 } \\
\text { 食倸数 } \\
D_{m, j} \\
\end{array}$} & $\mathrm{SS}_{\mathrm{R}}$ & 0.008 & 0.002 & 0.008 & 0.150 & 0.300 & 0.150 \\
\hline & $\mathrm{SS}_{\mathrm{L}}$ & 0.015 & 0.003 & 0.015 & & 0.038 & \\
\hline & $\mathrm{SS}_{\mathrm{I}}$ & 0.060 & 0.015 & \begin{tabular}{|l}
0.060 \\
\end{tabular} & & 0.150 & \\
\hline \multirow{3}{*}{$\Delta S_{j}^{l}$} & $\overline{\mathrm{SS}_{\mathrm{R}}}$ & & 0 & & $5 * 10^{-7}$ & $6 * 10^{-7}$ & $5 * 10^{-7}$ \\
\hline & $\mathrm{SS}_{\mathrm{L}}$ & & 0 & & $5 * 10^{-7}$ & $6 * 10^{-7}$ & $5 * 10^{-7}$ \\
\hline & $\mathrm{SS}_{\mathrm{I}}$ & & 0 & & & $1 * 10^{-6}$ & \\
\hline \multirow{3}{*}{$S_{\text {max }, j}^{l}$} & $\mathrm{SS}_{\mathrm{R}}$ & & $1 * 10^{-3}$ & & & $3 * 10^{-4}$ & \\
\hline & $\mathrm{SS}_{\mathrm{L}}$ & & $1 * 10^{-3}$ & & & $3 * 10^{-4}$ & \\
\hline & $\mathrm{SS}_{\mathrm{I}}$ & & $1 * 10^{-2}$ & & $5 * 10^{-4}$ & $6^{*} 10^{-4}$ & $5 * 10^{-4}$ \\
\hline \multirow{3}{*}{$S_{\min , j}^{l}$} & $\mathrm{SS}_{\mathrm{R}}$ & & $1 * 10^{-4}$ & & $3 * 10^{-7}$ & $4 * 10^{-7}$ & $3 * 10^{-7}$ \\
\hline & $\mathrm{SS}_{\mathrm{L}}$ & & $1 * 10^{-4}$ & & $3 * 10^{-7}$ & $4 * 10^{-7}$ & $3 * 10^{-7}$ \\
\hline & $\mathrm{SS}_{\mathrm{I}}$ & & $1 * 10^{-3}$ & & $6 * 10^{-7}$ & $8 * 10^{-7}$ & $6 * 10^{-7}$ \\
\hline
\end{tabular}
である. 地表面上の土砂堆積量 $S^{l}{ }_{j}$ は, 無降雨時におけ
表-2 モデル係数 （河道流モデル (a), 地表流モデル (b) )

\begin{tabular}{|l|r|r|r|}
\hline \multicolumn{1}{|c|}{ (a) } & $\begin{array}{c}\text { 難分解性有 } \\
\text { 機体SS:SS }\end{array}$ & $\begin{array}{c}\text { 易分解性有 } \\
\text { 機体SS:SS }\end{array}$ & $\begin{array}{c}\text { 無機態 } \\
\mathrm{SS}_{\mathrm{L}} \mathrm{SS}_{\mathrm{I}}\end{array}$ \\
\hline$k_{u}[-]$ & $3 * 10^{-5}$ & $3 * 10^{-5}$ & $3 * 10^{-5}$ \\
\hline$\beta[-]$ & 2 & 2 & 2 \\
\hline$k_{S S}[1 /$ day $]$ & 0 & 0.4 & 0 \\
\hline$k_{p}[1 /$ day $]$ & 0 & 0.4 & 0 \\
\hline
\end{tabular}

る土砂堆砂速度 $\Delta S^{l}{ }_{j} \quad\left(\mathrm{~kg} /\left(\mathrm{m}^{2} \mathrm{hr}\right)\right)$ と上記の $L_{n p s, j}$ の流出 を考慮して, 以下の収支式より算出される.

$$
\frac{d S^{l}{ }_{j}}{d t}=\Delta S_{j}^{l}-L_{n p s, j}
$$

この計算を進めるに当たり， $S^{l}{ }_{j}$ が負となることや，市 街地での一般的な知見 ${ }^{17)}$ と異なり $S^{l}{ }_{j}$ が上限無く増加し 続けることを避けるため, ここでは, 上限值 $S^{l}{ }_{\max , j}$ と下 限值 $S_{\text {min, } j}^{l}$ を設ける. なお, ここで用いられているパラ メータ $\alpha_{1}, \alpha_{2}, D_{m, j}, S_{\max , j}^{l}, S_{\min , j}^{l}$ は表-2に示すも のを採用している。 また，式(1)ではSS全体の収支式を設 けているが，実際には，三種類のSSごとに収支式を解い ており，用いられるパラメータも同表のように異なるも のが設定されている.

水田からの面源負荷は, 式(2)の土銥流出負荷に加え, 灌溉用水負荷, 欠口からの流出負荷, 代择き期の流出負 荷を考慮している. 基本的な考え方は佐藤ら ${ }^{13)}$ と同じで あるので，ここでは省略する.

\section{2) 河道流モデル}

河道流モデルにおけるSS輸送の扱いに関しては，地表 流と同様に, 河道流中のSS濃度 $C^{r}$ と単位面積当たりの土 砂堆積量 $S^{r} \quad\left(\mathrm{~kg} / \mathrm{m}^{2}\right)$ の収支を考える. SS濃度に関して は，一次元移流方程式を基礎とし，河道外部からの流入 負荷 $L_{r}$, 再浮上, 沈降, 分解を考慮した次式を用いる. 


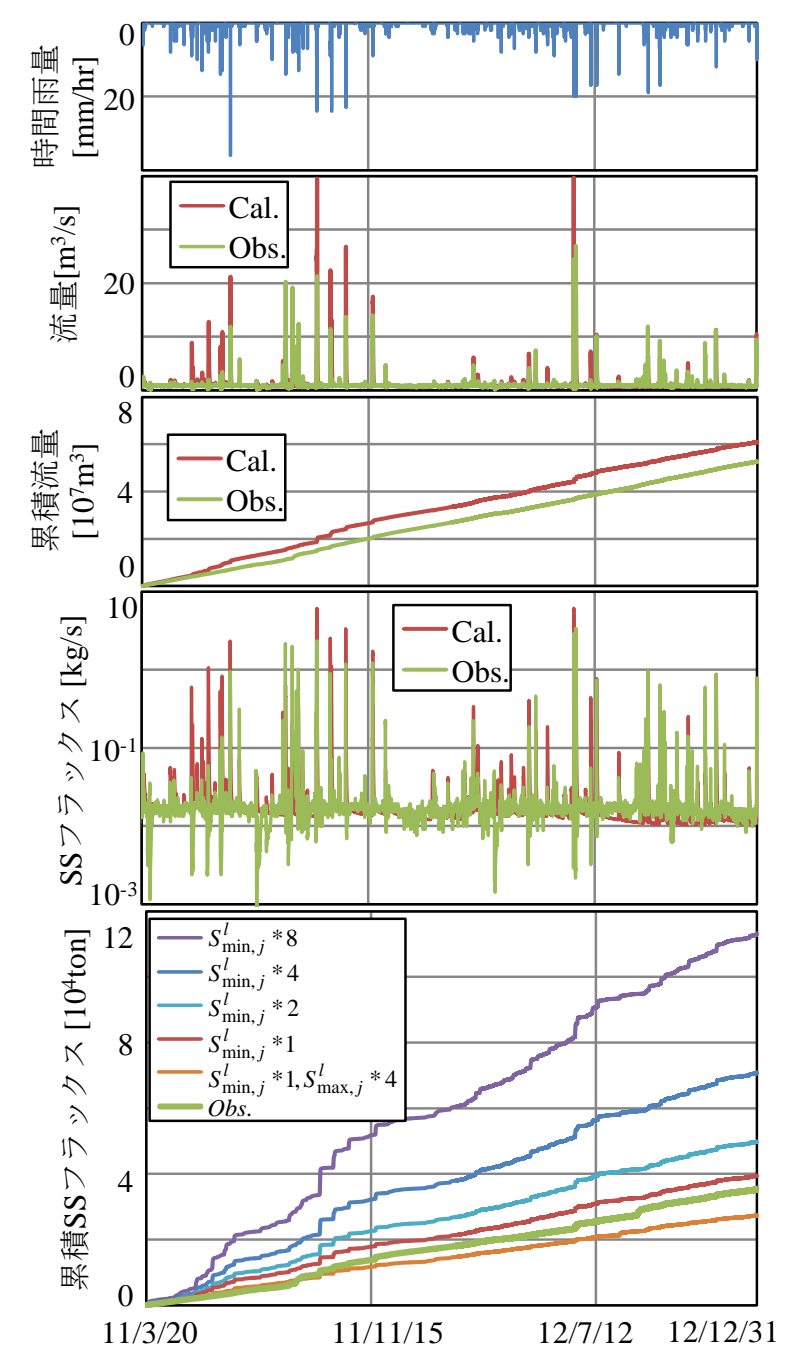

図-3 時間雨量（観測值）と本流域 SS モデルによる流量 · 累 積流量 - SS フラックス · 累積 SS フラックスの時間変化（大堀 川・呼塚橋)

$\frac{\partial C^{r}}{\partial t}+u \frac{\partial C^{r}}{\partial x}=L_{r}+\frac{k_{u} \cdot S^{r} u^{\beta}}{h}-\frac{w_{0} \cdot C^{r}}{h}-k_{S S} \cdot C^{r}$

ここで, $u$ は流速 $(\mathrm{m} / \mathrm{s}), k_{u}, \beta$ は再浮上に関するパラメ 一タ, $w_{0}$ は沈降速度 $(\mathrm{m} / \mathrm{s}), h$ は水深 $(\mathrm{m})$ である.上 記の右辺第2, 3項は, 底面での再浮上, 沈降フラックス を水深で除している. また，この沈降速度 $w_{0}$ は，ストー クスの式より与える.

$$
w_{0}=\frac{g\left(\rho_{S}-\rho_{w}\right) \cdot d^{2}}{18 \mu}
$$

$\rho_{s}$ とdはSS粒子の密度と粒径, $\mu$ は水の粘性係数である. また，単位面積当たりの土砂堆積量 $S^{r}$ の収支式は，

$$
\frac{d S^{r}}{d t}=w_{0} \cdot C^{r}-k_{u} \cdot S^{r} \cdot u^{\beta}-k_{p} \cdot S^{r}
$$

ここで. $k_{p}$ は自浄化係数 (易分解性有機態 $\mathrm{SS}_{\mathrm{L}}$ のみ考慮, 1/hr) である. これらのパラメータを表-2に示す.

\section{3）計算条件}

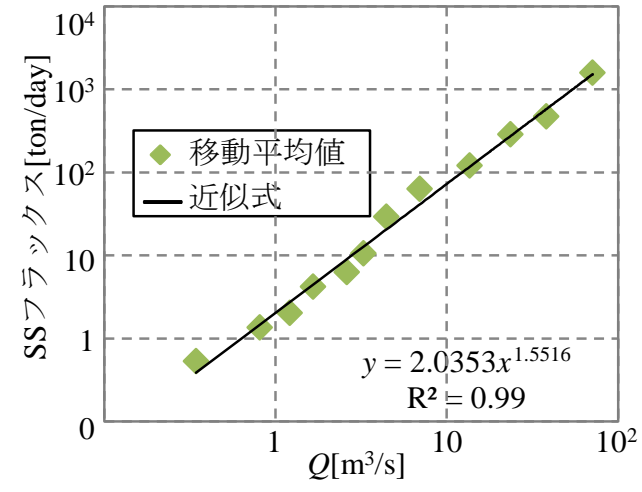

図-4ＳS フラックス観測值用の $L-Q$ 式 ${ }^{18)}$

本論文では，手賀沼流域全体を $100 \mathrm{~m}$ 四方の正方メッシ ユで分割して計算を行った．今回は，流域内の土砂動態 を解析対象とした. 計算実施期間は2011/1/1～2012/12/31 と する. また，予備計算として一ヶ月間を確保している.

\section{3. 結果と考察}

\section{(1) 流域SS動態モデルの検証}

本研究で用いる流域SS動態モデルの基本的な有効性を 検証するために，観測データが存在する大堀川・呼塚橋 (河口から $1.5 \mathrm{~km}$ 上流) における流量, 累積流量, SSフラ ックス，累積SSフラックスの計算值の時間変化を図-3に 示す.ここでは，時間雨量の観測值（千葉県手賀沼）の 結果も示す。また, 流量・累積流量・SSフラックスは観 測值と一つの計算值のみ示すが，累積SSフラックスに関 しては，観測值とモデルパラメータ $\left(S_{\max , j}^{l}, \quad S_{\min , j}^{l}\right)$ を変化させた計算值を示す. パラメータの組合せとして は, 表-2における $S^{l}{ }_{\max , j}, S^{l}{ }_{\text {min }, j}$ を基準にして, $S_{\text {min, } j}^{l}$ のみ $1 ， 2 ， 4 ， 8$ 倍, また， $S_{\text {max }, j}^{l}$ の夕4倍にした計5ケー スを選定した. また，SSフラックスの観測值としては， 当該地点で過去に行われた土砂輸送量調査結果 ${ }^{18)}$ から得 られる $L Q$ 式を用いている（図-4）。なお，ここでは，原 発事故が発生し, 関東で放射能污染が顕著になった 2011/3/20から2012/12/31までの時間変化を図示している.

まず，流量に関しては，平常時は概ね一致するが，降 雨時にはやや過大評価していることが分かる．累積流量 に関しても，これらの結果が反映されており，計算值が 観測值をやや上回っており，最終的には流量の累積值の 計算結果は観測結果の1.16倍となった。この值は, 流量の 観測誤差を鑑みると十分な計算精度といえる.

次に, SSフラックスに着目すると, 観測值と計算值は 概ね類似した変化傾向となっている. また, 累積SSフラ ックスに関しても，パラメータフィッティングを経て得 られた表-2のパラメータセットの結果は，観測值と概ね 類似している，これより，本流域SSモデルの基本的な有 効性が検証された，その上，表-2は本計算対象に適合し 


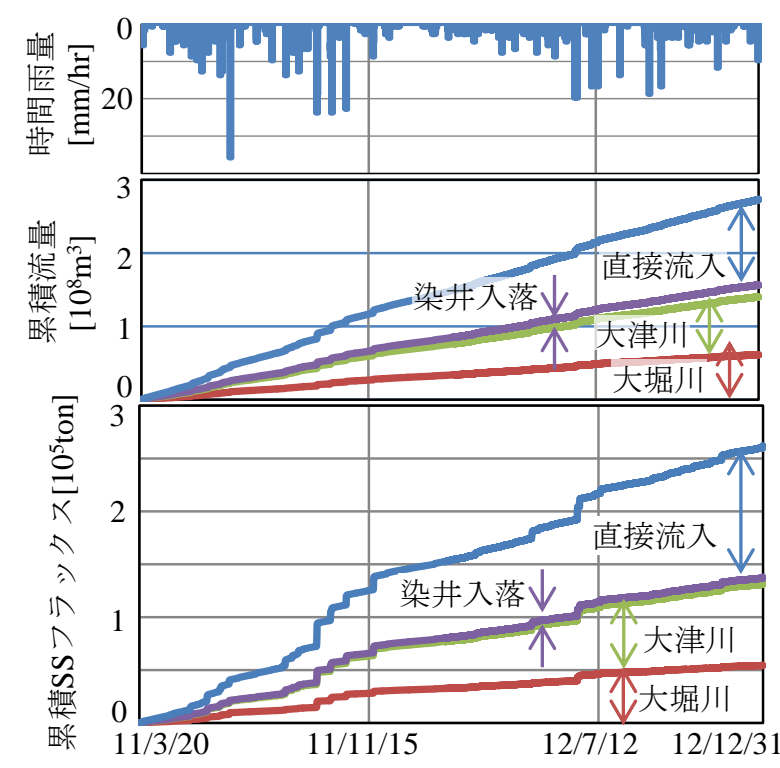

図-5 流域全体の累積流量・SS フラックスの時間変化

たパラメータ群といえる．また，二つのパラメータのう ち， $S_{\text {min, } j}^{l}$ を大きくすると, SS輸送量は大きくなる.こ れは，地表面における堆積物の下限值が大きくなると， 運ばれる堆積物自体が多くなるためである。また，

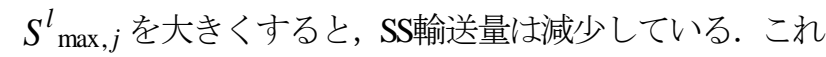
は，本モデル上の式（2c）に示されるように，地表面上 の土畩流出量 $L_{n p s, j}$ が小さくなるためである.

図-5は，手賀沼流域全体における累積流量・SSフラッ クスの計算值の時間変化を示している.ここでは，流域 全体を大堀川，大津川，染井入落，その他の直接流入域 の 4 つに分けて表示している. このように, 流量の大き い大堀川や大津川からのSSフラックスの寄与が大きいと 共に，直接流入域からの寄与も見られる．また，本対象 期間終了時における全体の累積SSフラックスに対する大 堀川, 大津川, 染井入落, 直接流入域の寄与はそれぞれ 20.9\%，29.5\%，2.3\%，47.4\%であった.

\section{(2) 流域 ・河川における放射性CS濃度の推移}

モニタリング結果に基づく, 都市流域の堆積土砂や河 川底泥中の放射性CS濃度の推移を図-6に示寸。ここでは, 大堀川流域における路面と屋根面，河川（呼塚橋，河口 から $1.5 \mathrm{~km})$ の結果を図示している ${ }^{11)}$ 。これより，全ての データに関して放射性セシウムは減少していることが分 かる．特に，路面での減少量が顕著となっている．Cs濃 度の減少量 $\Delta C s$ は放射性崩壊分 $\Delta C s_{r}$ 及びその他の効果 (ここでは新規堆積土砂との混合による減少分） $\Delta C s_{m}$ の和と見なされる ${ }^{11)}, \Delta C s_{r}$ は次式より与えられる.

$$
\Delta C s_{r}=C s_{0}\left\{1-\exp \left(-\frac{0.693}{T_{r}} t\right)\right\}
$$

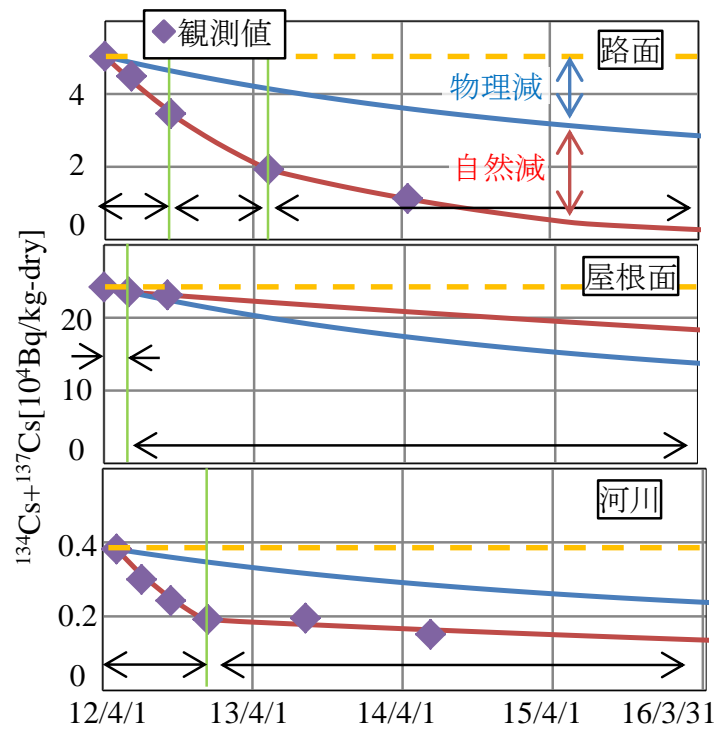

図-6 流域（路面, 屋根面） - 河川の放射性 Cs の経年変化

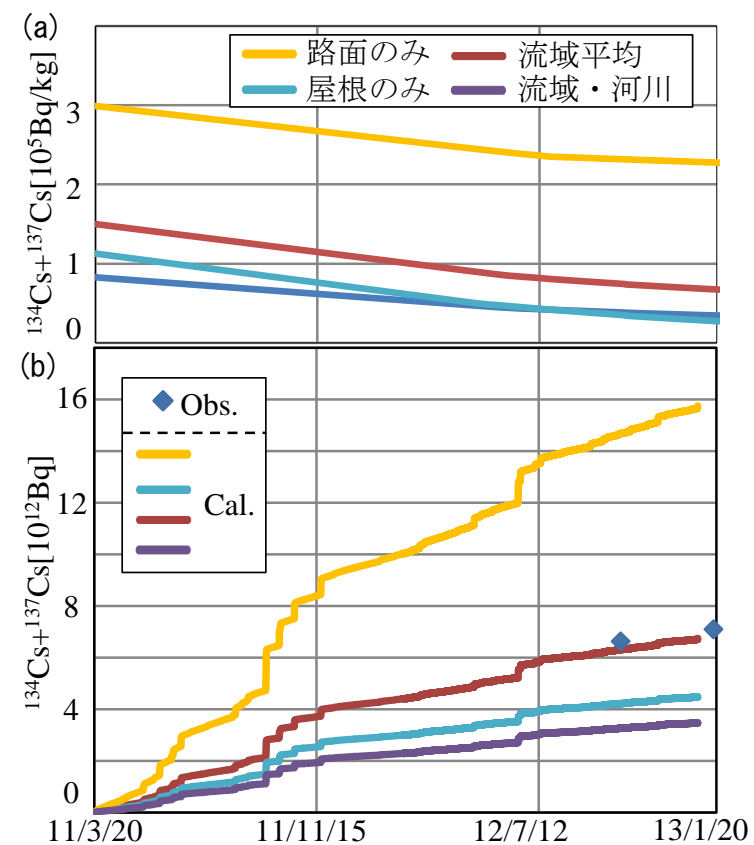

図-7 流域から供給される放射性Cs 濃度の推定值 (a)およびCs 供給量の観測値と推定値 (b) の時間変化

ここで， $T_{r}$ は放射性崩壊による物理的半減期である．観 測值を補間・補外して長期連続的なCsデータを得るため に，観測值にこれらの近似式を当てはめたところ，Csの 減少状況が時期により異なった。 そこで，うまくフイッ ティングすべく，図中の矢印のように期間を分けて近似 式を作成した結果が図-6に表示されている，なお，減少 量の小さかった屋根面では減少量 $\Delta C s$ を2分割せずにそ のまま式(7)を近似式として当てはめている.これらの結 果より, 路面の放射性Csの減少率は時間と共に低くなっ ており，放射能污染が長期化の様相を呈している. 
得られた近似式に基づいて，流域から河川に流れ込む SS中に含まれる放射性CS濃度の推定を行う。ここでは, 河川水中のSSが流域堆積物の久を起源とすることを想定 し ${ }^{10)}$ ，手賀沼流域の半分以上が市街地であることを考慮 して，(1)路面のみ，(2)屋根面のみ，(3)流域平均（路面： 屋根面 $=8: 2$ 割合で混合) ${ }^{19}$ に加えて, 河川底泥からの 影響を加味した(4)流域・河川平均（路面 : 屋根面 : 河川 底泥 $=4: 1: 5$ の割合で混合）の計4ケースを想定する. 得られた推定結果は図-7(a)に示寸とおりである.

これら4つの放射性Csの推定值が時及刻々のSS中の放 射性Cs含有量と仮定し，それを流域SS動態モデルで算出 した流域全体から手賀沼へのSS流入量（図-5）に掛けて 得られた放射性Cs供給量を図-7(b)に示寸．また，手賀沼 での放射性Csのストック量を求め，それを観測值として いる ${ }^{10)}$ 。これより, 4つの推定值のうち, 流域平均の結果 が観測值と一致していることが分かる．そのため，今後 の放射能污染の推移を見るには，流域平均の放射性Cs濃 度を用いる必要があることが分かる．ただし，湖面沈着 の影響等は考慮しておらず，観測值の数も十分でなく， 本解析期間も2012年末までと短いため，今後は，対象期 間を延ばすと共に, より多くの観測值との比較が必要と なる.

\section{5. 結論}

本研究における結論は以下の通りである.

1）水・物質循環モデル（SIPHERモデル）をベースとし た流域SS動態モデルを構築し，手賀沼流域に適用し た. 大堀川における河川流量やSS輸送量の観測值と 本計算結果が概ね一致したことから，本モデルの基 本的な有效性が検証された。

2）放射能污染に関するモニタリング結果より, 都市流 域の路面や屋根面ともに放射性CSは減少しているも のの, 路面の放射性Csの減少率は時間と共に低くな っており，放射能污染の長期化が懸念される.

3）流域からの放射性Csの供給量を求めた結果, 流域平 均の放射性C濃度を使用した推定值と観測值は概ね 一致し, 本研究で用いた手法による放射性Cs供給量 評価に関する一定の妥当性が示された.

謝辞: 本論文では, 千葉県河川環境課から降雨量データ, 同水質保全課から排出污濁負荷量をご提供頂いた。ここ に記して謝意を表します。

\section{参考文献}

1) 首相官邸 HP : http:/www.kantei.go.jp/saigai/anzen.html（閲覧日：
2014年9月 24 日）.

2) J. C. Ritchie and J. R. Mchenry: Application of radioactive fallout Cesium-137 for measuring soil erosion and sediment accumulation rates and pattems: a review,J. Environ. Qual., Vol.19, pp.215-233, 1990.

3) 田中万也, 坂口綾, 岩谷北斗, 高橋嘉夫 : 福島第一原子力 発電所事故由来の放射性セシウムの環境中での移行挙動と ミクロスケールでの不均質性, 放射化学, Vol.27, pp.12-19, 2013.

4) チェルノブイリ・フォーラム専門家グループ（日本学術会 議訳）：チェルノブイリ原発事故による環境への影響とそ の修復 : 20年の経験, pp.81-107, 2006.

5) 高橋正通 : 福島県の森林の放射性セシウム污染の実態と長 期モニタリング，学術の動向，Vol.18，No.6, pp.6_68-6_71, 2013.

6) 吉田聡 : 森林生態系での放射性物質動態一過去の研究事例 から予測される状況と課題一, 森林科学, Vol.65, pp.31-33, 2012.

7) 中尾淳 : セシウムの土㙵吸着と固定, 学術の動向, Vol.17, No.10, pp.10_40-10_45, 2012.

8) 塩沢昌, 田野井慶太郎, 根本圭介, 吉田修一朗, 西田和弘, 橋本健, 桜井健太, 中西友子, 二瓶直登, 小野勇治 : 福島 県の水田土㙥における放射性セシウムの深度別濃度と移 流速度, RADIOISOTOPES, Vol.60, pp.27-32, 2011.

9) 尾崎則篤 : 市街地における放射性物質の流出 一文献調査 結果とそこから得られた知見-, 第 17 回日本水環境学会シ ンポジウム, 107p., 2014.

10) 二瓶泰雄, 大内田崇享, 笹川一磨, 橋田創, 武川一樹 : 都 市流域一河川一湖沼における放射性セシウム 134, 137の動 態 〜手賀沼流域を例に〜，土木学会論文集B1（水工学）， Vol.69, No.4, pp.I_1693-I_1698, 2013.

11）橋田創, 二瓶泰雄, 大内田崇享, 笹川一磨, 小松有由美 : 手賀沼流域圈における放射性セシウムの推移と魚類への影 響, 土木学会論文集B1 (水工学), Vol.70, No.4, pp.I_1411-I_1416, 2014.

12) 千葉県 HP : http://www.pref.chiba.g.jp/kouhou/saigai/h23touhokuhoushasen.html（閲覧日：2014年9月 17 日）.

13）佐藤祐一，小松英司，永禮英明，上原浩，湯浅岳史，大久 保卓也. 岡本高弘, 金再奎 : 陸域一湖内流動一湖内生態系 を結合した琵琶湖流域水循環モデルの構築とその検証，水 環境学会誌，Vol.34, No.9, pp.125-141， 2011.

14）山田安彦, 白鳥孝治, 立本英機 : 印旛沼 - 手賀沼一水環境 への提言一, 古今書院, pp.1-167, 1993.

15）文部科学省 HP : http://ramap.jaea.go.jp/map/map.htm\#（閲覧日： 2014年9月 17 日）.

16) D. M. Hartley: simplified process model for water and sediment yield from single storms, Transactions of the ASCE, Vol.30, No.3,pp.710-723, 1987.

17) 二瓶泰雄, 砂田岳彦, 水野智之 : 模擬降雨流出水採取法に 基づく路面塵埃環境の時間的・空間的变動特性の把握，水 環境学会誌, Vol.29, No.5, pp.261-268, 2006.

18）田中健太郎，二瓶泰雄 : SS モニタリングネットワークに基 づく東京湾への浮遊土砂供給特性の把握, 水工学論文集, Vol.55, pp.S_1327-S_1332, 2011.

19) 二瓶泰雄, 吉田拓司, 砂田岳彦: 屋根面堆積負荷の非定常 挙動に関する連続観測, 水環境学会誌, Vol.29, No.11, pp.755-760, 2006.

(2014. 9.30 受付) 